\title{
Ruthenium and Iron Complexes with Benzotriazole and Benzimidazole Derivatives as Simple Models for Proton-Coupled Electron Transfer Systems
}

\author{
Reginaldo C. Rocha, Francisca N. Rein and Henrique E. Toma*
}

Instituto de Química, Universidade de São Paulo, C. P. 26077, 05513-970, São Paulo - SP, Brazil.

\begin{abstract}
Complexos de ferro e rutênio do tipo $[\mathrm{M}-\mathrm{LH}]^{n}$ (onde $\mathrm{M}=\mathrm{Ru}^{\mathrm{II}, \mathrm{III}}\left(\mathrm{NH}_{3}\right)_{5}{ }^{2+, 3+}, \mathrm{Ru}$ II,III $(\text { edta })^{2-,-}$ [edta = etilenodinitrilotetraacetato], ou Fe $\mathrm{II}^{\mathrm{IIII}}(\mathrm{CN})_{5}{ }^{3-, 2-}$ e $\mathrm{LH}=$ benzotriazol ou benzoimidazol) foram preparados e caracterizados em solução aquosa através de métodos eletroquímicos e espectroeletroquímicos. Neste trabalho, maior ênfase foi direcionada aos processos redox dependentes do $\mathrm{pH}$, que foram demonstrados por todos os complexos estudados. Os valores de $\mathrm{p} K_{\mathrm{a}}$ e de potencial de redução formal foram obtidos a partir dos diagramas de $E_{1 / 2}$ versus $\mathrm{pH}$, que apresentaram comportamento tipicamente Nernstiano. Os diagramas de Pourbaix também foram usados para ilustrar o particionamento entre as espécies redox e os equilíbrios ácido-base envolvidos nas reações. Na avaliação da potencialidade desses complexos como modelos simples para reações de transferência de elétrons acoplada a próton (PCET), considerou-se a extensão da região onde a dependência do par redox $\mathrm{M}^{\mathrm{III}} / \mathrm{M}^{\mathrm{II}}$ com o $\mathrm{pH}$ é ativa, definida entre $\mathrm{p} K_{\mathrm{a}}^{\mathrm{III}} \mathrm{e} \mathrm{p} K_{\mathrm{a}}{ }_{\mathrm{a}}$. Os resultados obtidos neste trabalho foram analisados do ponto de vista do caráter eletrônico doador/receptor dos ligantes e das interações $\sigma, \pi$-metal-ligante envolvidas em cada espécie, para ambos os estados de oxidação do íon metálico.
\end{abstract}

Iron and ruthenium complexes of the type $[\mathrm{M}-\mathrm{LH}]^{n}$ (where $\mathrm{M}=\mathrm{Ru}^{\mathrm{II}}, \mathrm{III}\left(\mathrm{NH}_{3}\right)_{5}{ }^{2+, 3+}$, $\mathrm{Ru}^{\mathrm{II}, \mathrm{III}}(\mathrm{edta})^{2-,-}$ [edta $=$ ethylenedinitrilotetraacetate], or Fe $\mathrm{Fe}^{\mathrm{II}, \mathrm{III}}(\mathrm{CN})_{5}{ }^{3-, 2-}$ and $\mathrm{LH}=$ benzotriazole or benzimidazole) were prepared and characterized in aqueous solutions by means of electrochemical and spectroelectrochemical methods. Special emphasis was given to the $\mathrm{pH}$-dependent redox processes, exhibited by all the investigated complexes. From their related Pourbaix diagrams, which displayed a typically Nernstian behavior, the $\mathrm{p} K_{\mathrm{a}}$ and formal reduction potential values were extracted. In addition, these $E_{1 / 2}$ versus $\mathrm{pH}$ curves were also used to illustrate the partitioning relationship concerning the redox and acid-base species, and their interconversion equilibria. The active area in which the dependence of the $\mathrm{M}^{\mathrm{III}} / \mathrm{M}^{\mathrm{II}}$ couple on the $\mathrm{pH}$ takes place, as delimited by $\mathrm{p} K_{\mathrm{a}}^{\mathrm{III}}$ and $\mathrm{p} K_{\mathrm{a}}^{\mathrm{II}}$, was taken into account in order to evaluate the usefulness of such simple complexes as models for proton-coupled electron transfer (PCET). The results were interpreted in terms of the acceptor/ donor electronic character of the ligands and $\sigma, \pi$-metal-ligand interactions in both redox states of the metal ion.

Keywords: ruthenium complexes, iron complexes, monoacid N-heterocycles, redox potentials, pH-dependent electrochemistry

\section{Introduction}

Proton-coupled electron transfer (PCET) is known to play an important pathway of charge transport in a variety of aqueous electrochemical processes ${ }^{1,2}$ and biochemical ${ }^{3,4}$, inorganic $^{5}$ and organic reactions $s^{4,5}$. Recent developments in supramolecular solid-state chemistry are directed toward rational design of PCET systems with novel electronic or photonic material properties ${ }^{6}$. The overall redox mechanisms, however, are often quite complex, involving multiple electron and proton transfers. But, by limiting the inner coordination

\footnotetext{
*e-mail: henetoma@iq.usp.br
}

sphere to one ionizable proton, it is possible to obtain complexes which exhibit one-electron, one-proton redox reactions over relatively broad $\mathrm{pH}$ and potential regions ${ }^{5}$. In order to develop simple models for PCET, we have synthesized coordinatively saturated, substitutionally inert transition-metal complexes such that oxidation of the metal is coupled to proton transfer at a remote site on the coordinated acid N-heterocyclic ligand.

In this direction, ruthenium ${ }^{7}$ and iron ${ }^{8,9}$ complexes with $d^{5} / d^{6}$ configurations are very useful due to their rich and versatile redox chemistry, in addition to their usually favorable kinetic properties and stability. Heterocyclic nitrogens play in turn an important role in coordination 
chemistry ${ }^{10}$. Imidazole, for instance, is an ubiquitous ligand ${ }^{11}$ in chemical and biological systems as it appears as such in proteins, and, together with its derivatives, have been extensively employed as models in a wide range of inorganic subject areas, from biological applications to electronic devices and materials ${ }^{12,13}$. The triazole derivatives have also been largely studied in ruthenium and osmium chemistry of discrete or supermolecules ${ }^{14}$. In particular, benzotriazole is largely employed as an efficient corrosion inhibitor for copper and its alloys ${ }^{15}$ and provides a model ligand for bioinorganic studies involving the interaction of nucleic bases or DNA fragments and transition metal complexes. Nevertheless, its coordination chemistry with iron and second-row transition metals has been little explored.

Although the reactivity and the properties of transition metal complexes with imidazole and triazole derivatives have been studied over the last decades, a few cases involving the interaction of the benzimidazole (bimH) and benzotriazole (btaH) ligands (Scheme 1) with iron(II,III) and ruthenium(II,III) complexes are known ${ }^{16-22}$. Actually, to the best of our knowledge, we have investigated the coordination chemistry of benzotriazole with pentacyano-ferrate(II)/ (III) $^{17,21}$, pentaammineruthenium(II)/(III) ${ }^{18,21,22}$ and ethylenediaminetetraacetatoruthenium (II)/(III) ${ }^{19,20,22}$ for the first time. In this present work, a larger series involving these metal units was studied, by including a structural analogue of the benzotriazole ligand (namely, benzimidazole). We explored in detail the relationship between the acid-base equilibria and electrochemistry, focusing on their proton-coupled electron transfer (PCET) reactions.

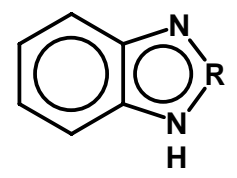

LH

benzotriazole (btaH): $\mathrm{R}=\mathbf{N}$
benzimidazole $(\mathbf{b i m H}): \mathbf{R}=\mathbf{C H}$

Scheme 1.

\section{Experimental}

Syntheses and preparation of compounds

Chemicals. $\mathrm{RuCl}_{3} \cdot \mathrm{nH}_{2} \mathrm{O}$ (Inco Europe Ltd.), $\left[\mathrm{Ru}\left(\mathrm{NH}_{3}\right)_{6}\right] \mathrm{Cl}_{3}$ (Johnson Matthey Chem.; recrystallized), $\mathrm{Na}_{2}\left[\mathrm{Fe}(\mathrm{CN})_{5} \mathrm{NO}\right]$ (J.T.Baker), benzimidazole and benzotriazole (Aldrich Chem.). All organic solvents employed in the syntheses were analytical reagent grade and were used without further purification. Deionized water (Nanopure $^{\mathrm{TM}}$-Barnstead) was used through out the experiments. Other chemicals used here were also purchased from Sigma-Aldrich Co. and used as supplied. Argon gas (White-Martins) was employed to deaerate the solutions during the experiments.

Starting materials. $\mathrm{Na}_{3}\left[\mathrm{Fe}(\mathrm{CN})_{5}\left(\mathrm{NH}_{3}\right)\right]^{23},\left[\mathrm{Ru}\left(\mathrm{NH}_{3}\right)_{5}\right.$ $\mathrm{Cl}] \mathrm{Cl}_{2}{ }^{24}$ and $\mathrm{Ru}\left(\right.$ Hedta) $\mathrm{H}_{2} \mathrm{O}^{25}$ were synthesized according to the procedures previously reported in the literature. Elemental analyses, spectroscopic and electrochemical methods were used to assess the purity of the compounds.

$\left[\mathrm{Ru}^{n}\left(\mathrm{NH}_{3}\right)_{5}(\mathrm{LH})\right]\left(\mathrm{PF}_{6}\right)_{n} \times x \mathrm{H}_{2} \mathrm{O}$ (where $\mathrm{LH}=$ bimH or $b t a H)$. In the preparation of the ammineruthenium derivatives, $58.6 \mathrm{mg}$ of $\left[\mathrm{Ru}\left(\mathrm{NH}_{3}\right)_{5} \mathrm{Cl}\right] \mathrm{Cl}_{2}(0.2 \mathrm{mmol})$ were dissolved in $5 \mathrm{~cm}^{3}$ of degassed water, after which some amalgamated zinc pieces were added. After reacting for $30 \mathrm{~min}$, the resulting yellow solution was anaerobically transferred to a recipient containing $238.2 \mathrm{mg}$ of benzotriazole or $236.2 \mathrm{mg}$ of benzimidazole $(2.0 \mathrm{mmol})$ under an argon atmosphere (in the benzimidazole case, $5 \%$ in volume of ethanol was previously added to make the dissolution of the ligand easier), and left for $30 \mathrm{~min}$. Then, $5 \mathrm{~cm}^{3}$ of a concentrated ammonium hexafluoro-phosphate was dripped onto the orange color reactional mixture. A yellow precipitate was immediately formed. The solid product was collected on a filter, washed with a small volume of ethanol, and dried in vacuum in the presence of anhydrous calcium chloride. Yield: $80-90 \%$.

In the case of the benzimidazole derivative, the yellow solid becomes rapidly reddish in the presence of air, indicating its conversion to the $\mathrm{Ru}^{\mathrm{III}}$ species (similar observations have been reported for several imidazole derivatives) ${ }^{12}$. For convenience, the isolated solid was then redissolved in water and completely oxidized by passing a flow of $\mathrm{O}_{2}$ through the solution. After adding about $50 \mathrm{mg}$ of solid ammonium hexafluorophosphate, a red product was isolated from the slow evaporation of the concentrated solutions. The final yield slightly decreased to $c a$. $75-80 \%$.

Anal. Calcd. for $\mathrm{C}_{7} \mathrm{H}_{25} \mathrm{~N}_{7} \mathrm{O}_{2} \mathrm{~F}_{18} \mathrm{P}_{3} \mathrm{Ru}$ (bimH; $\mathrm{MM}=$ 775.3; weight of product: $115-122 \mathrm{mg}$ ): $\mathrm{C}, 10.84 ; \mathrm{H}, 3.25$; $\mathrm{N}, 12.65$. Found: $\mathrm{C}, 10.79 ; \mathrm{H}, 3.31 ; \mathrm{N}, 12.62 \%$. Anal. Calcd. for $\mathrm{C}_{6} \mathrm{H}_{26} \mathrm{~N}_{8} \mathrm{O}_{3} \mathrm{~F}_{12} \mathrm{P}_{2} \mathrm{Ru}$ (btaH; $\mathrm{MM}=649.3$; weight of product: $100-105 \mathrm{mg}$ ): C, $11.10 ; \mathrm{H}, 4.04 ; \mathrm{N}, 17.26$. Found: C, $10.95 ; \mathrm{H}, 4.11 ; \mathrm{N}, 17.04 \%$.

$\mathrm{Ru}^{\mathrm{III}}(\mathrm{Hedta})(\mathrm{LH}) \times 3 \mathrm{H}_{2} \mathrm{O}$ (where $\mathrm{LH}=$ bimH or btaH). The edta-complexes were obtained by mixing $480.4 \mathrm{mg}$ of $\left[\mathrm{Ru}(\mathrm{Hedta})\left(\mathrm{H}_{2} \mathrm{O}\right)\right] \times 3 \mathrm{H}_{2} \mathrm{O}(1.0 \mathrm{mmol})$ and $141.7 \mathrm{mg}$ of benzimidazole or $142.9 \mathrm{mg}$ of benzotriazole $(1.2 \mathrm{mmol})$ in $20.0 \mathrm{~cm}^{3}$ of $\mathrm{H}_{2} \mathrm{O}$ /ethanol 3:1, under argon. 15 min later, the pale yellow mixture was evaporated under low pressure using a rotatory evaporator up to $3-5 \mathrm{~cm}^{3}$, after which $15 \mathrm{~cm}^{3}$ of cold acetone was added dropwise. The flaked yellow 
precipitate was collected on a filter, washed with a 2:1 acetone/ ethanol mixture and kept under vacuum. Yield: 85-90\%.

Anal. Calcd. for $\mathrm{C}_{17} \mathrm{H}_{25} \mathrm{~N}_{4} \mathrm{O}_{11} \mathrm{Ru}$ (bimH; $\mathrm{MM}=562.5$; weight of product: $475-500 \mathrm{mg}): \mathrm{C}, 36.30 ; \mathrm{H}, 4.48 ; \mathrm{N}$, 9.96. Found: C, 36.29; H, 4.63; N, 9.92\%. Anal. Calcd. for $\mathrm{C}_{16} \mathrm{H}_{24} \mathrm{~N}_{5} \mathrm{O}_{11} \mathrm{Ru}$ (btaH; $\mathrm{MM}=563.5$; weight of product: 480-510 mg): C, 34.11; H, 4.29; N, 12.43. Found: C, 34.22; $\mathrm{H}, 4.41 ; \mathrm{N}, 12.52 \%$.

$\mathrm{Na}_{3}\left[\mathrm{Fe}^{\mathrm{II}}(\mathrm{CN})_{5}(\mathrm{LH})\right] \times x \mathrm{H}_{2} \mathrm{O}$ (where $\mathrm{LH}=$ bimH or btaH). The cyano-iron complexes were obtained by adding $326.0 \mathrm{mg}$ of $\mathrm{Na}_{3}\left[\mathrm{Fe}(\mathrm{CN})_{5}\left(\mathrm{NH}_{3}\right)\right] \times 3 \mathrm{H}_{2} \mathrm{O}(1.0 \mathrm{mmol})$ to $20.0 \mathrm{~cm}^{3}$ of a deoxygenated $\mathrm{H}_{2} \mathrm{O}$ /ethanol 3:1 solution containing $177.2 \mathrm{mg}$ of benzimidazole or $178.7 \mathrm{mg}$ of benzotriazole ( $1.5 \mathrm{mmol})$. After $20 \mathrm{~min}$, the yellow mixture was evaporated under vacuum up to $3-5 \mathrm{~cm}^{3}$. Then, 15 $\mathrm{cm}^{3}$ of cold acetone was dripped on the solution. The precipitate was collected by filtration, washed with a $2: 1$ acetone/ethanol mixture, and dried under vacuum in the presence of anhydrous calcium chloride. Yield: $80-85 \%$.

Anal. Calcd. for $\mathrm{C}_{12} \mathrm{H}_{14} \mathrm{~N}_{7} \mathrm{O}_{4} \mathrm{FeNa}_{3}$ (bimH; $\mathrm{MM}=$ 445.1; weight of product: $355-375 \mathrm{mg}$ ): C, 32.38; H, 3.17; N, 22.03. Found: C, 32.44; H, 3.23; N, 21.96\%. Anal. Calcd. for $\mathrm{C}_{11} \mathrm{H}_{11} \mathrm{~N}_{8} \mathrm{O}_{3} \mathrm{FeNa}_{3}$ (btaH; $\mathrm{MM}=428.1$; weight of product: $350-365 \mathrm{mg}$ ): C, 30.86; H, 2.59; N, 26.18. Found: C, 30.93; H, 2.66; N, 26.13\%.

Aqueous solutions. Alternatively, all the complexes were freshly prepared in aqueous solutions as follows: $0.025 \mathrm{mmol}$ of the starting complex (i.e., $\mathrm{Na}_{3}\left[\mathrm{Fe}(\mathrm{CN})_{5}\left(\mathrm{NH}_{3}\right)\right],\left[\mathrm{Ru}\left(\mathrm{NH}_{3}\right)_{5} \mathrm{Cl}\right] \mathrm{Cl}_{2}$, or $\left.\mathrm{Ru}(\mathrm{Hedta}) \mathrm{H}_{2} \mathrm{O}\right)$ was added, under anaerobic conditions, to $5.0 \mathrm{~cm}^{3}$ of a $0.10 \mathrm{~mol} \mathrm{dm}^{-3}$ PIPES buffered solution (PIPES = piperazine-N,N'-bis[2-ethanesulfonic acid]; $\mathrm{pH} 7.0$ ) containing an amount of $0.050 \mathrm{mmol}$ of the ligand and $5 \%$ of ethanol (in volume) to make the dissolution of the ligand easier (particularly for the benzimidazole). Then, the $\mathrm{pH}$ of the solutions was adjusted by carefully controlling (with the use of high-precision microvolumetric syringes) the addition of $3.0 \mathrm{~mol} \mathrm{dm}^{-3}$ sodium hydroxide or hydrochloric acid solution, as required. Sodium trifluoroacetate (NaTFA) 0.10 mol dm${ }^{-3}$ was employed as supporting electrolyte for the electrochemical and spectroelectrochemical measurements.

The purity of the complexes prepared in-situ was assessed by means of cyclic voltammetry, which presented in all samples only one reversible wave couple for the product (whose redox potential was rather distinguishable from the starting complex). In addition, the freshly prepared solutions from either the isolated solid or directly from the in-situ mixture of the reagent species showed identical cyclic voltammograms and electronic spectra.

Measurements for solutions at $\mathrm{pH}$ above 6.5 were run under an argon atmosphere. This procedure avoids, for instance, further oxidation processes involving the edtaruthenium(III) complex ${ }^{26}$. All prolonged-time measurements involving the photo-sensitive $\left[\mathrm{Fe}(\mathrm{CN})_{5}\right]^{2-/ 3}$ - derivatives were also run in the presence of reduced light. This procedure avoids further substitution processes involving the cyanide ligands.

Acid-base spectrophotometric titration. For determining the $\mathrm{p} K_{\mathrm{a}}$ of the complexes, the complexes were prepared in a modified Britton-Robinson ${ }^{27}$ buffer ( $\left.\mathrm{pH} 2-12\right)$ solution, which has been prepared by mixing acetic $\left(0.03 \mathrm{~mol} \mathrm{dm}^{-3}\right)$, PIPES $\left(0.04 \mathrm{~mol} \mathrm{dm}^{-3}\right)$ and boric $\left(0.03 \mathrm{~mol} \mathrm{dm}^{-3}\right)$ acids. The $\mathrm{pH}$ of the solutions was adjusted by the controlled addition of $3.0 \mathrm{~mol} \mathrm{dm}^{-3}$ sodium hydroxide or hydrochloric acid solution, as required.

\section{Physicochemical measurements}

The electronic spectra were recorded on a HewlettPackard model 8453 diode-array spectrophotometer.

Cyclic and differential pulse voltammetry measurements were carried out using a Princeton Applied Research - PAR model 283 potentiostat/galvanostat. A conventional three-electrode arrangement was employed in the measurements; it consists of a glassy carbon working electrode, a Luggin capillary with $\mathrm{Ag} / \mathrm{AgCl}(\mathrm{KCl} 1.0 \mathrm{~mol}$ $\left.\mathrm{dm}^{-3}\right)$ reference electrode $\left(E^{\mathrm{o}}=0.222 \mathrm{~V}\right.$ versus $\left.\mathrm{SHE}\right)$, and a platinum wire as the auxiliary electrode, in aqueous solutions containing sodium trifluoroacetate as supporting electrolyte. All solutions were thoroughly degassed with argon prior to beginning the experiments, and before each measurement the solutions were purged with inert gas. All $E_{1 / 2}$ values are uncorrected for junction potentials.

For the spectroelectrochemical measurements, a Princeton Applied Research - PAR model 173 potentiostat or a model 366 bi-potentiostat was used in parallel with the diode-array spectrophotometer. A three-electrode system was designed for a rectangular quartz cell of $0.025 \mathrm{~cm}$ internal optical path length. A gold minigrid was used as a transparent working electrode, in the presence of a small $\mathrm{Ag} / \mathrm{AgCl}$ reference electrode and a platinum auxiliary electrode. The cell was located directly in the spectrophotometer, and the absorption change was monitored during the electrolysis.

The $\mathrm{p} K_{\mathrm{a}}$ values were determined by cyclic voltammetry measurements as a function of $\mathrm{pH}$. An electrochemical cell was specially designed, in order to combine simultaneous $\mathrm{pH}$ measurements with cyclic voltammograms.

$\mathrm{pH}$ measurements were carried out with a digital $\mathrm{pH}$ meter mod. MD21 from Digimed Ltda. Calibration was performed by using $\mathrm{pH} 4.00,7.00$ and 10.00 commercial standard buffers.

Elemental analyses were obtained by Central Analítica - Instituto de Química, Universidade de São Paulo. 


\section{Results}

The reactivity of the benzotriazole and benzotriazolate mononuclear derivatives was already discussed elsewhere ${ }^{17-19}$. The benzimidazole/benzimidazolate species, on the other hand, are being reported for the first time. Even so, only their PCET related properties will be stressed in this contribution, in such a way that the spectral features of both derivatives will no longer be outlined in details in the sections below. Instead, they are collected in tables, for comparison and discussion purposes.

Complexes $\left[\mathrm{Ru}^{\mathrm{II}, I I I}\left(\mathrm{NH}_{3}\right)_{5}(\mathrm{LH})\right]^{2+, 3+}$ and $\left[\mathrm{Ru}^{I I I I I I}\left(\mathrm{NH}_{3}\right)_{5}(L)\right]^{+, 2+}\left(\mathrm{L}=\mathrm{bta}^{-}\right.$or bim $\left.{ }^{-}\right)$

In an aqueous solution, the starting complex pentaammine(chloro)ruthenium(II), $\left[\mathrm{Ru}\left(\mathrm{NH}_{3}\right)_{5} \mathrm{Cl}\right]^{+}$, reacts rapidly to form the aquapentaammineruthenium(II), $\left[\mathrm{Ru}\left(\mathrm{NH}_{3}\right)_{5}\right.$ $\left.\left(\mathrm{H}_{2} \mathrm{O}\right)\right]^{2+}$. This aqua-complex is labile and exchanges the water easily in the presence of $\mathrm{N}$-heterocyclic ligands ${ }^{28}$, yielding the corresponding substituted complexes.

The cyclic voltammograms of the $\left[\mathrm{Ru}\left(\mathrm{NH}_{3}\right)_{5}(\mathrm{LH})\right]^{2+}$ products exhibited a systematic dependence on the acidity/ basicity of the medium, from which the $E_{1 / 2}$ vs. pH diagrams were built (Figures 1a and 2a).

Complexes [Ru III,II $($ edta $)(L H)]^{-, 2-}$ and $\left[R u^{I I I, I I}(e d t a)(L)\right]^{2-, 3-}\left(L=b_{t a}^{-}\right.$or bim $\left.{ }^{-}\right)$

The starting complex aqua(ethylenediaminetetraacetato)ruthenate(III), $\mathrm{Ru}^{\mathrm{III}}($ Hedta $)\left(\mathrm{H}_{2} \mathrm{O}\right)$, undergoes two deprotonation processes, with acid-base equilibrium constants corresponding to $\mathrm{p} K_{\mathrm{a}}^{(1)}=2.37$ and $\mathrm{p} K_{\mathrm{a}}^{(2)}=7.60^{29}$ :

$\left[\mathrm{Ru}(\right.$ Hedta $\left.)\left(\mathrm{H}_{2} \mathrm{O}\right)\right] \stackrel{K_{\mathrm{a}}^{(\mathrm{l})}}{\rightleftharpoons}\left[\mathrm{Ru}(\text { edta })\left(\mathrm{H}_{2} \mathrm{O}\right)\right]^{-}+\mathrm{H}^{+}$

$\left[\mathrm{Ru}(\text { edta })\left(\mathrm{H}_{2} \mathrm{O}\right)\right]^{-} \stackrel{K_{\mathrm{a}}^{(2)}}{\rightleftharpoons}[\mathrm{Ru}(\text { edta })(\mathrm{OH})]^{2-}+\mathrm{H}^{+}$

The $\left[\mathrm{Ru}^{\mathrm{III}}(\text { edta })\left(\mathrm{H}_{2} \mathrm{O}\right)\right]^{-}$species, generated from the dissolution of $\left[\mathrm{Ru}^{\mathrm{III}}(\mathrm{Hedta})\left(\mathrm{H}_{2} \mathrm{O}\right)\right]$ in an aqueous solution ( $\mathrm{pH}>3$ ), exhibits an unusually labile coordination site and reacts rapidly with many ligands via an associative mechanism ${ }^{29}$.

The complexes of the type $[\mathrm{Ru}(\mathrm{edta})(\mathrm{LH})]^{-}$also presented $\mathrm{pH}$-dependence on their redox potentials, as illustrated in Figures $1 b$ and $2 b^{30}$.

Complexes $\left[\mathrm{Fe}^{\mathrm{II}, \mathrm{III}}(\mathrm{CN})_{5}(\mathrm{LH})\right]^{3-, 2-}$ and $\left[\mathrm{Fe}^{I I, I I I}(\mathrm{CN})_{5}(L)\right]^{4-, 3-}\left(\mathrm{L}=\mathrm{bta}^{-}\right.$or bim $\left.{ }^{-}\right)$

In a slightly acidic aqueous solution, the amminepentacyanoferrate(II) ion, $\left[\mathrm{Fe}(\mathrm{CN})_{5}\left(\mathrm{NH}_{3}\right)\right]^{3-}$, undergoes

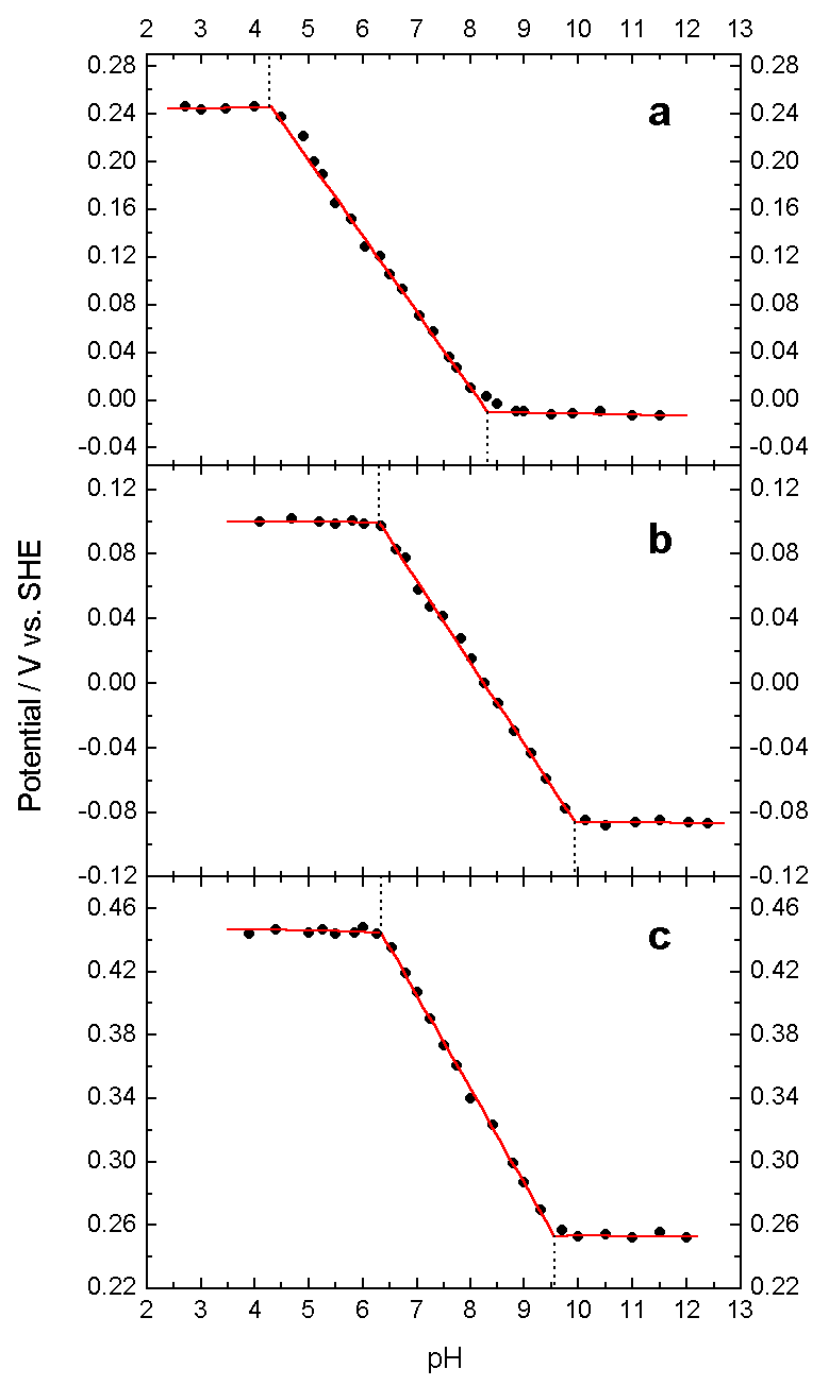

Figure 1. pH-potential diagrams for (a) $\left[\mathrm{Ru}\left(\mathrm{NH}_{3}\right)_{5}(\mathrm{btaH})\right]^{2+}$, (b) $[\mathrm{Ru}(\text { edta })(\mathrm{btaH})]^{-}$, and $(\mathbf{c})\left[\mathrm{Fe}(\mathrm{CN})_{5}(\mathrm{btaH})\right]^{3-}$.

substitution of ammonia to form the corresponding aquacomplex, $\left[\mathrm{Fe}(\mathrm{CN})_{5}\left(\mathrm{H}_{2} \mathrm{O}\right)\right]^{3-31}$, which in turn reacts readily with $\mathrm{N}$-heterocyclic ligands 9 .

The reaction of aquapentacyanoferrate(II) with benzotriazole and benzimidazole (twice in excess) in an aqueous solution gives complexes whose acid-base equilibria for the coordinated ligands, $\left[\mathrm{Fe}(\mathrm{CN})_{5}(\mathrm{LH})\right]^{3-}$, were investigated. Their $\mathrm{pH}$-potential diagrams can be seen in Figures 1c and 2c, respectively ${ }^{30}$.

An important comment on the electrochemical behavior of the studied systems is required before advancing the discussion of the results: while the cyclic voltammograms of the benzimidazole derivatives displayed a single wave couple, which was reversible over all the investigated $\mathrm{pH}$ range, in the $1 \mathrm{H}$-benzotriazole species an additional anodic wave of low current intensity and shifted by about 100 $\mathrm{mV}$ to more positive potentials appeared in the voltammograms. This process has been assigned ${ }^{17-19}$ to 


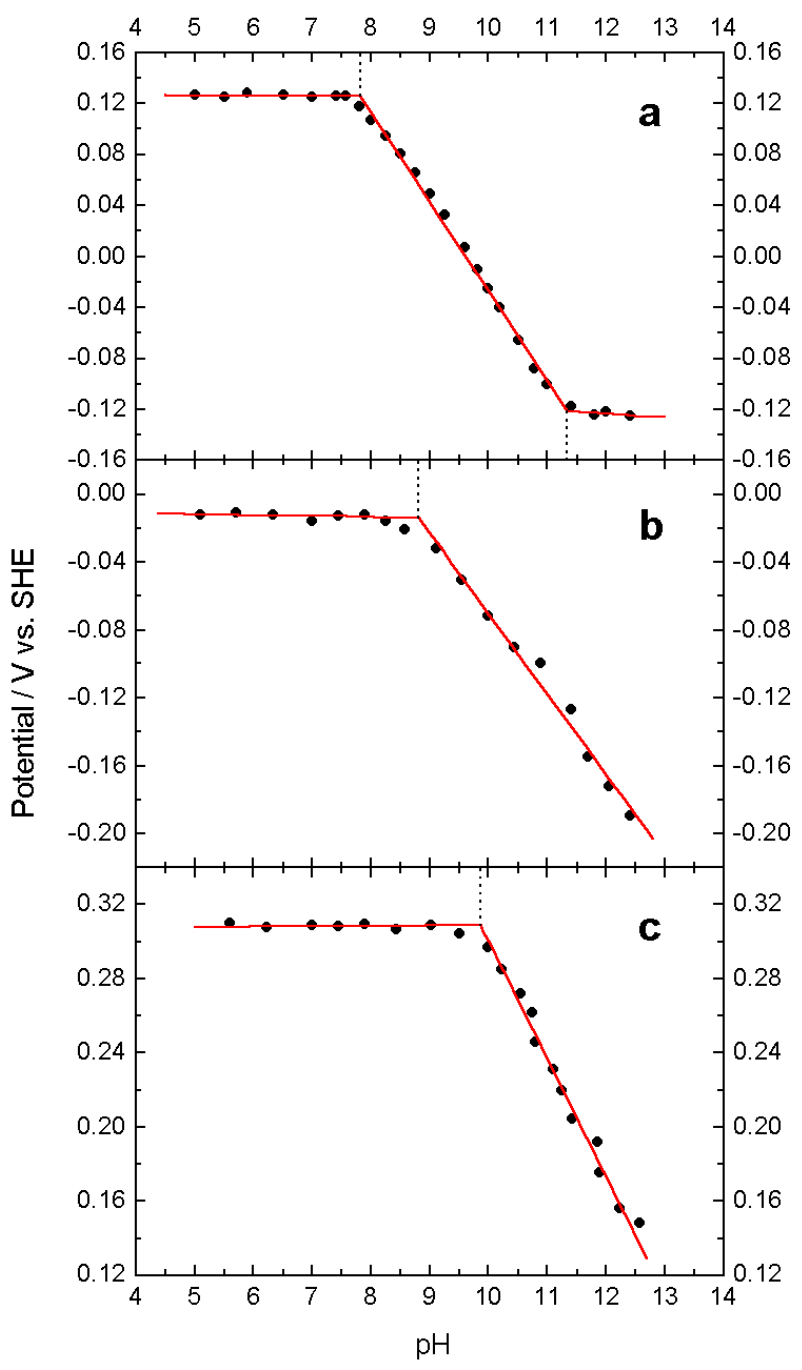

Figure 2. pH-potential diagrams for (a) $\left[\mathrm{Ru}\left(\mathrm{NH}_{3}\right)_{5}(\mathrm{bimH})\right]^{2+}$, (b) $\left[\mathrm{Ru}(\text { edta) }(\mathrm{bimH})]^{-}\right.$, and $(\mathrm{c})\left[\mathrm{Fe}(\mathrm{CN})_{5}(\mathrm{bimH})\right]^{3-}$.

the partial isomerization from the complex formulated as $[\mathrm{M}-\mathrm{N} 3-\mathrm{btaH}]$ to the $[\mathrm{M}-\mathrm{N} 2-\mathrm{btaH}]$ one. Since this chemical process (isomerism) follows the electrochemical step (reduction) and the $[\mathrm{M}-\mathrm{N} 2-\mathrm{btaH}]$ species practically does not exist in the oxidized form ${ }^{17,19}$, only the redox potentials associated with the reversible wave $\left(\mathrm{M}^{\mathrm{III} / \mathrm{II}}\right.$ N3-btaH couple) will be taken for all purposes involving proton-dependence related features.

\section{Discussion}

If a ligand containing an ionizable proton is coordinated to a metal ion, its acidity generally increases due to stabilization of the conjugate base by the metal cation ${ }^{5,32}$. Since increasing the charge of the cation usually stabilizes the anionic conjugate base, it follows that the coordinated ligand becomes more acidic when the charge of the cation is increased. Therefore, the acid dissociation constant $\left(K_{\mathrm{a}}\right)$ of the complex increases with the oxidation state of the metal ${ }^{19,33}$. Consequently, a metal-localized redox process shows a pH-dependent couple if deprotonation (protonation) of the ligand occurs upon oxidation (reduction) of the complex in the $\mathrm{pH}$ range studied. The observation of $\mathrm{pH}$-dependent potentials is, therefore, a powerful tool for recognizing proton-coupled redox processes 5 .

As the reactions investigated herein are of the type expressed by Eq. (3) and occur with a concomitant change in proton content, then the driving force for the ET reaction depends on the concentration of the hydrogen ion; hence, the electron transfer and proton transfer processes are considered to be coupled, which is readily indicated by the presence of the proton in the half reaction.

$\mathrm{M}^{\mathrm{III}} \mathrm{L}+\mathrm{H}^{+}+\mathrm{e}^{-} \rightleftharpoons \mathrm{M}^{\mathrm{II}} \mathrm{LH}$

The half-wave potential $\left(E_{1 / 2}\right.$; experimentally measured by cyclic $^{34,35}$ or differential pulse voltammetry ${ }^{34,36}$ ) is predicted to have a $\mathrm{pH}$ dependence according to the Nernst equation ${ }^{34}$, which in the particular case of one-electron/one-proton redox couples, as in Eq. (3), reduces to a simplified expression (Eq. (4)). This equation considers that the diffusion coefficients $D_{\mathrm{ox}}$ and $D_{\text {red }}$ are very similar for such systems and can often be assumed as being equal; $E^{\mathrm{o}}$ is the hypothetical formal potential at $\mathrm{pH} 0$.

$E_{1 / 2}=E^{\mathrm{o}},-0.059 \mathrm{pH}$

The dependence of redox potential upon the hydrogen ion concentration is conveniently visualized in a $\mathrm{pH}$ potential diagram, commonly referred to as a Pourbaix diagram ${ }^{2,37}$, or predominance area diagram. The parameters defining such a $\mathrm{pH}$-potential diagram, for a oneelectron redox process involving a hypothetical $\mathrm{M}^{\mathrm{III} / \mathrm{II}} \mathrm{LH}$ complex containing a single ionizable proton (i.e., exactly as the ones studied herein), are shown in Figure 3.

The horizontal lines in the acidic and basic $\mathrm{pH}$ regions represent the $\mathrm{pH}$-independent redox processes in which both the oxidized and reduced species are protonated (Eq. (5)) or deprotonated (Eq. (6)), respectively.

$$
\begin{aligned}
& \mathrm{M}^{\mathrm{III}} \mathrm{LH}^{+}+\mathrm{e}^{-} \rightleftharpoons \mathrm{M}^{\mathrm{II}} \mathrm{LH} \\
& \mathrm{M}^{\mathrm{III} L}+\mathrm{e}^{-} \rightleftharpoons \mathrm{M}^{\mathrm{II}} \mathrm{L}^{-}
\end{aligned}
$$

The diagonal line corresponds to the $\mathrm{pH}$-dependent redox process where reduction/oxidation of the metal center is coupled to protonation/deprotonation of the ligand (see Eq. (3)). The slope of this line is $59 \mathrm{mV} / \mathrm{pH}$ unit according 


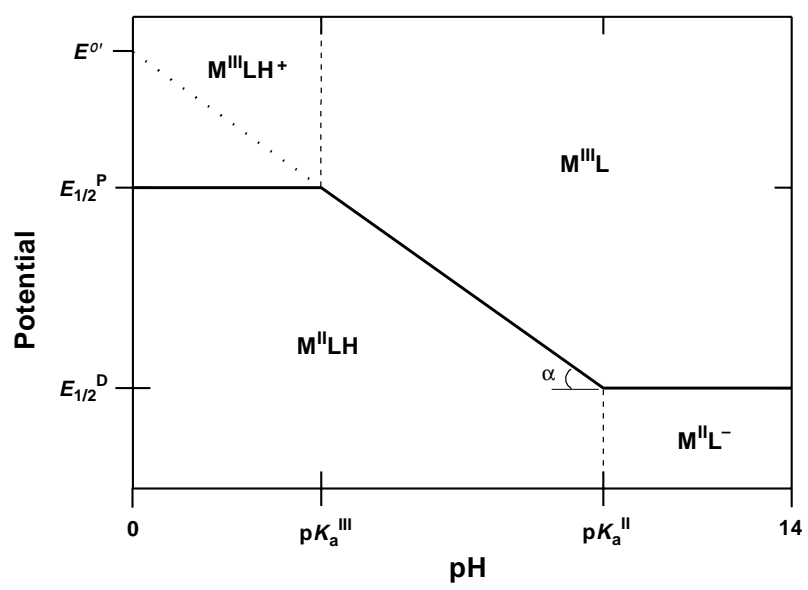

Figure 3. pH-potential diagram for a complex of the type $\mathrm{M}^{\mathrm{II}} \mathrm{LH}$ exhibiting a pH-dependent $\mathrm{M}^{\mathrm{III}} / \mathrm{M}^{\mathrm{II}}$ couple, where the slope $\alpha$ is 59 $\mathrm{mV} / \mathrm{pH} ; E^{o}$ is the formal potential of the $\mathrm{M}^{\mathrm{II}} \mathrm{L} / \mathrm{M}^{\mathrm{II}} \mathrm{LH}$ couple (at $\mathrm{pH}=$ $0) ; E_{1 / 2}{ }^{\mathrm{P}}$ is the formal potential of the $\mathrm{M}^{\mathrm{III}} \mathrm{LH}^{+} / \mathrm{M}^{\mathrm{II}} \mathrm{LH}$ couple; $E_{1 / 2}{ }^{\mathrm{D}}$ is the formal potential of the $\mathrm{M}^{\mathrm{III}} \mathrm{L} / \mathrm{M}^{\mathrm{II}} \mathrm{L}^{-}$couple; and $\mathrm{p} K_{\mathrm{a}}^{\mathrm{III}}$ and $\mathrm{p} K_{\mathrm{a}}{ }^{\mathrm{II}}$ are the $\mathrm{p} K_{\mathrm{a}}$ values of the $\mathrm{M}$ (III) and $\mathrm{M}$ (II) species, respectively (adapted from ref. 5).

to Eq. (4) for a one-electron, one-proton electrochemical process. The vertical lines in the acidic and basic $\mathrm{pH}$ regions represent the acid/base equilibrium for the oxidized (Eq. (7)) and reduced (Eqs. (8)) complexes, for which the acid dissociation constants are given by $K_{\mathrm{a}}^{\mathrm{III}}=\left[\mathrm{M}^{\mathrm{III}} \mathrm{L}\right]\left[\mathrm{H}^{+}\right] /$ $\left[\mathrm{M}^{\mathrm{III}} \mathrm{LH}^{+}\right]$and $K_{\mathrm{a}}^{\mathrm{II}}=\left[\mathrm{M}^{\mathrm{II}} \mathrm{L}^{-}\right]\left[\mathrm{H}^{+}\right] /\left[\mathrm{M}^{\mathrm{II}} \mathrm{LH}\right]$.

$$
\begin{aligned}
& \mathrm{M}^{\mathrm{III}} \mathrm{LH}^{+} \rightleftharpoons \mathrm{M}^{\mathrm{III}} \mathrm{L}+\mathrm{H}^{+} \\
& \mathrm{M}^{\mathrm{II}} \mathrm{LH} \rightleftharpoons \mathrm{M}^{\mathrm{II}} \mathrm{L}^{-}+\mathrm{H}^{+}
\end{aligned}
$$

The horizontal line in the acidic region corresponds to the potential at which $\left[\mathrm{M}^{\mathrm{III}} \mathrm{LH}^{+}\right]=\left[\mathrm{M}^{\mathrm{II}} \mathrm{LH}\right]$, while the diagonal line corresponds to $\left[\mathrm{M}^{\mathrm{III}} \mathrm{L}\right]=\left[\mathrm{M}^{\mathrm{II}} \mathrm{LH}\right]$. At the intersection point, $\left[\mathrm{M}^{\mathrm{III}} \mathrm{LH}^{+}\right]=\left[\mathrm{M}^{\mathrm{II}} \mathrm{LH}\right]=\left[\mathrm{M}^{\mathrm{III}} \mathrm{L}\right]$ and $K_{\mathrm{a}}^{\mathrm{III}}$ $=\left[\mathrm{H}^{+}\right]$. Hence, $\mathrm{p} K_{\mathrm{a}}^{\mathrm{III}}$ is equal to $\mathrm{pH}$ at the vertical line in the acidic region. By a similar argument, $\mathrm{p} K_{\mathrm{a}}^{\mathrm{II}}=\mathrm{pH}$ at the vertical line in the basic region.

As shown by the profiles of the $E_{1 / 2}$ versus $\mathrm{pH}$ diagrams in Figures 1 and 2, all the complexes within the investigated series displayed proton-coupled redox reactions which are consistent with the expected Nernstian behavior for one-electron/one-proton couples, as generically introduced above. A very important proof of that is provided by their slope values, which were very close to the predicted value of $-59 \mathrm{mV} / \mathrm{pH}$ unit (see Table 1).

In addition, all the electrode reactions arisen from the one-electron $\mathrm{M}^{\mathrm{III}} / \mathrm{M}^{\mathrm{II}}$ redox couples were electrochemically reversible. The reversibility was shown by the difference in anodic and cathodic peak potentials from the cyclic voltammetry experiments $\left(\Delta E_{\mathrm{p}}=60-70 \mathrm{mV}\right)^{34}$. In addition, the current intensities $\left(i_{\text {peak }}\right)$ for the reduction couple were plotted against the corresponding scan rates, showing square root dependence. This behavior is characteristic of a diffusion controlled process ${ }^{34}$. In such type of reaction, the number of electrons $n$ involved in the process can be estimated from the theoretical peak to peak $\left(E_{\text {anodic }}-E_{\text {cathodic }}\right.$ ) separation, which is $59 \mathrm{mV} / n$.

All the reported complexes of the type M-LH, and their

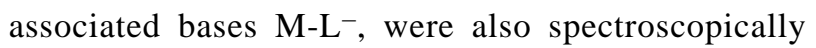
characterized in aqueous solutions, as summarized in Table 2.

From Tables 1 and 2 one can conclude that, unlike the pyridine and pyrazine derivatives (where the $\pi$-acceptor character usually prevails), benzotriazole/ benzotriazolate and benzimidazole/benzimidazolate behave essentially as $\pi$-donor ligands, leading to a preferential stabilization of the $\mathrm{M}^{\mathrm{III}}-\mathrm{LH}^{+}$or $\mathrm{M}^{\mathrm{III}}-\mathrm{L}$ complexes. That is why the reduction potentials for them are relatively lower (more negative) than other similar N-heterocycle complexes.

In some benzimidazole-complexes (particularly in the ruthenium-edta and cyano-iron ones), their $\mathrm{p} K_{\mathrm{a}}$ for the reduced species (named herein as $\mathrm{p} K_{\mathrm{a}}^{\mathrm{II}}$ ) is so high that they could not be electrochemically determined, since above $\mathrm{pH}$ 12 , the cyclic voltammetry response is too poor, and the stability of the complexes becomes poorer as well. Although $\mathrm{p} K_{\mathrm{a}}{ }_{\mathrm{II}}$ were not precisely estimated in these examples, their superior limit (up to the maximum $\mathrm{pH}$ where the potentials were successfully measured) are indicated in Table 1.

Analysis of the spectral results related to ligand-to-metal (LMCT) and metal-to-ligand charge transfer (MLCT) transitions, suggests that benzimidazole and its conjugate base, benzimidazolate, are both stronger electron-donors than their benzotriazole and benzotriazolate analogues. That is, the

\begin{tabular}{|c|c|c|c|c|c|c|c|c|}
\hline Complex & $\mathrm{p} K_{\mathrm{a}}^{\mathrm{III}}$ & $\mathrm{p} K_{\mathrm{a}}{ }^{\mathrm{II}}$ & $\Delta \mathrm{p} K_{\mathrm{a}}{ }^{a}$ & $\begin{array}{l}E_{1 / 2} \mathrm{P} \\
(\mathrm{V})^{b}\end{array}$ & $\begin{array}{l}E_{1 / 2}{ }^{\mathrm{D}} \\
(\mathrm{V})^{b}\end{array}$ & $\begin{array}{c}\Delta E_{1 / 2}{ }^{c} \\
(\mathrm{mV})\end{array}$ & $\begin{array}{l}E^{o, d} \\
(\mathrm{~V})\end{array}$ & $\begin{array}{c}\text { slope } \\
(\mathrm{mV} / \mathrm{pH})\end{array}$ \\
\hline$\left[\mathrm{Ru}\left(\mathrm{NH}_{3}\right)_{5}(\mathrm{btaH})\right]^{\mathrm{n}+}$ & 4.32 & 8.33 & 4.01 & 0.245 & -0.012 & 257 & 0.522 & -63.9 \\
\hline$\left[\mathrm{Ru}\left(\mathrm{NH}_{3}\right)_{5}(\mathrm{bimH})\right]^{\mathrm{n}+}$ & 7.82 & 11.36 & 3.54 & 0.127 & -0.125 & 252 & 0.674 & -69.0 \\
\hline$[\mathrm{Ru}(\mathrm{edta})(\mathrm{btaH})]^{\mathrm{n}-}$ & 6.31 & 9.94 & 3.63 & 0.100 & -0.086 & 186 & 0.422 & -54.7 \\
\hline$[\mathrm{Ru}(\mathrm{edta})(\mathrm{bimH})]^{\mathrm{n}-}$ & 8.82 & $>12^{e}$ & $>3.8$ & -0.011 & $<-0.20$ & $>180$ & 0.403 & -52.5 \\
\hline$\left[\mathrm{Fe}(\mathrm{CN})_{5}(\mathrm{btaH})\right]^{\mathrm{n}-}$ & 6.34 & 9.55 & 3.21 & 0.447 & 0.253 & 194 & 0.823 & -59.7 \\
\hline$\left[\mathrm{Fe}(\mathrm{CN})_{5}(\mathrm{bimH})\right]^{\mathrm{n}-}$ & 9.88 & $>12^{f}$ & $>2.6$ & 0.308 & $<0.14$ & $>170$ & 0.939 & -63.8 \\
\hline
\end{tabular}

Table 1. PCET parameters for the studied series of ruthenium and iron complexes. 
Table 2. Comparison of UV-Vis absorption spectra for the series of complexes.

\begin{tabular}{|c|c|c|}
\hline Complex & $\begin{array}{c}\text { LMCT } \\
\mathrm{nm}\left(\mathrm{mol}^{-1} \mathrm{dm}^{3} \mathrm{~cm}^{-1}\right)\end{array}$ & $\begin{array}{c}\text { MLCT } \\
\mathrm{nm}\left(\mathrm{mol}^{-1} \mathrm{dm}^{3} \mathrm{~cm}^{-1}\right)\end{array}$ \\
\hline $\begin{array}{l}{\left[\mathrm{Ru}^{\mathrm{III}}\left(\mathrm{NH}_{3}\right)_{5}(\mathrm{btaH})\right]^{3+}} \\
{\left[\mathrm{Ru}^{\mathrm{II}}\left(\mathrm{NH}_{3}\right)_{5}(\mathrm{btaH})\right]^{2+}} \\
{\left[\mathrm{Ru}^{\mathrm{III}}\left(\mathrm{NH}_{3}\right)_{5}(\mathrm{bta})\right]^{2+}} \\
{\left[\mathrm{Ru}^{\mathrm{II}}\left(\mathrm{NH}_{3}\right)_{5}(\mathrm{bta})\right]^{+}} \\
{\left[\mathrm{Ru}^{\mathrm{III}}\left(\mathrm{NH}_{3}\right)_{5}(\mathrm{bimH})\right]^{3+}} \\
{\left[\mathrm{Ru}^{\mathrm{II}}\left(\mathrm{NH}_{3}\right)_{5}(\mathrm{bimH})\right]^{2+}} \\
{\left[\mathrm{Ru}^{\mathrm{III}}\left(\mathrm{NH}_{3}\right)_{5}(\mathrm{bim})\right]^{2+}} \\
{\left[\mathrm{Ru}^{\mathrm{II}}\left(\mathrm{NH}_{3}\right)_{5}(\mathrm{bim})\right]^{+}}\end{array}$ & $\begin{array}{rl}327 ;^{a} 448 & b(660 ; 360) \\
325 ; a & - \\
467 & b(3650 ; 2060) \\
& - \\
445 & (1050) \\
- & - \\
500 & (1170) \\
- & \end{array}$ & $\begin{array}{c}- \\
410(11310) \\
- \\
389(7760) \\
- \\
360(1300) \\
\quad- \\
350(1000 ; \mathrm{sh})\end{array}$ \\
\hline $\begin{array}{l}{\left[\mathrm{Ru}^{\mathrm{III}}(\text { edta })(\mathrm{btaH})\right]^{-}} \\
{\left[\mathrm{Ru}^{\mathrm{II}}(\text { edta })(\mathrm{btaH})\right]^{2-}} \\
{\left[\mathrm{Ru}^{\mathrm{III}}(\text { edta })(\mathrm{bta})\right]^{2-}} \\
{\left[\mathrm{Ru}^{\mathrm{II}}(\text { edta })(\mathrm{bta})\right]^{3-}} \\
{\left[\mathrm{Ru}^{\mathrm{III}}(\text { edta })(\mathrm{bimH})\right]^{-}} \\
{\left[\mathrm{Ru}^{\mathrm{II}}(\text { edta })(\text { bimH })\right]^{2-}} \\
{\left[\mathrm{Ru}^{\mathrm{III}}(\text { edta })(\text { bim })\right]^{2-}} \\
{\left[\mathrm{Ru}^{\mathrm{II}}(\text { edta })(\text { bim })\right]^{3-}}\end{array}$ & $\begin{array}{c}350(\mathrm{sh})^{c} \\
- \\
510(1540) \\
- \\
360(1280) \\
- \\
520(350) \\
-\end{array}$ & $\begin{array}{c}- \\
400(6500) \\
- \\
395(6000) \\
- \\
330(3280) \\
\quad- \\
325(3060)\end{array}$ \\
\hline $\begin{array}{l}{\left[\mathrm{Fe}^{\mathrm{III}}(\mathrm{CN})_{5}(\mathrm{btaH})\right]^{2-}} \\
{\left[\mathrm{Fe}^{\mathrm{II}}(\mathrm{CN})_{5}(\mathrm{btaH})\right]^{3-}} \\
{\left[\mathrm{Fe}^{\mathrm{III}}(\mathrm{CN})_{5}(\mathrm{bta})\right]^{3-}} \\
\\
{\left[\mathrm{Fe}^{\mathrm{II}}(\mathrm{CN})_{5}(\mathrm{bta})\right]^{4-}} \\
{\left[\mathrm{Fe}^{\mathrm{III}}(\mathrm{CN})_{5}(\mathrm{bimH})\right]^{2-}} \\
{\left[\mathrm{Fe}^{\mathrm{II}}(\mathrm{CN})_{5}(\mathrm{bimH})\right]^{3-}} \\
{\left[\mathrm{Fe}^{\mathrm{III}}(\mathrm{CN})_{5}(\mathrm{bim})\right]^{3-}} \\
{\left[\mathrm{Fe}^{\mathrm{II}}(\mathrm{CN})_{5}(\mathrm{bim})\right]^{4-}}\end{array}$ & $\begin{array}{c}365(1170)^{d} \\
396 ; a^{a} 487^{b}(875 ; 1020) \\
- \\
365(990)^{d} \\
392 ; a 582^{b}(840 ; 2180) \\
- \\
505(1800) \\
- \\
610(1900) \\
-\end{array}$ & $\begin{aligned} & - \\
388 & (4440) \\
& - \\
350 & (2100) \\
& - \\
322 ; 430 & (1650 ; 380) \\
& - \\
320 ; 380 & (1500 ; 485)\end{aligned}$ \\
\hline
\end{tabular}

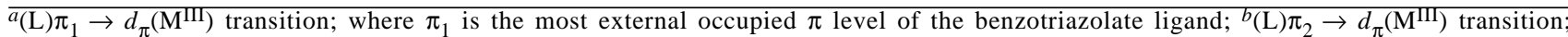
${ }^{c} \mathrm{Ru}(d \rightarrow d)$ transition; ${ }^{d}\left(\mathrm{CN}^{-}\right) \pi \rightarrow d_{\pi}\left(\mathrm{Fe}^{\mathrm{III}}\right)$ transition.

former derivative possesses a higher basic character than the latter one, which can be clearly observed through the set of acid-base and electrochemical parameters concerning their proton-coupled electron transfer reactions (Table 1).

Indeed, as the acidity of the ligand enhances when coordinated to a metal which has partially empty $d \pi$ orbitals (as in the case of the $d \pi^{5}$ ions), the $\pi$-donor capability of the ligands can be inferred by analyzing the variation (decrease) of $\mathrm{p} K_{\mathrm{a}}$ values on their coordination to the oxidized complexes of the type $\mathrm{M}^{\mathrm{III}} \mathrm{X}_{5}-\mathrm{LH}$ or $\mathrm{M}^{\mathrm{III}} \mathrm{X}_{5}-\mathrm{L}^{-}$(that is the so called $\pi$-effects). In this sense, while the $\Delta \mathrm{p} K_{\mathrm{a}}$ from the uncoordinated benzimidazole ligand $\left(\mathrm{p} K_{\mathrm{a}}=12.78 \pm 0.04\right)^{38}$ to the $\left[\mathrm{Ru}^{\mathrm{III}}\left(\mathrm{NH}_{3}\right)_{5}(\mathrm{LH})\right]^{3+}, \quad\left[\mathrm{Ru}^{\mathrm{III}}(\mathrm{edta})(\mathrm{LH})\right]^{-}, \quad$ and $\left[\mathrm{Fe}^{\mathrm{III}}(\mathrm{CN})_{5}(\mathrm{LH})\right]^{2-}$ complexes is 4.96, 3.96, and 2.90, respectively, the variation in the analogous series for benzotriazole (whose $\mathrm{p} K_{\mathrm{a}}$ in the free form is $8.38 \pm 0.03)^{39}$ is rather lower: $\Delta \mathrm{p} K_{\mathrm{a}}=4.06,2.07$, and 2.04. The greater relative stabilization of the coordinated benzimidazolate species in relation to the benzotriazolate ones reflects their higher $\pi$-donor character, i.e. they have their acidity more enhanced with coordination than benzotriazole, although the latter is a better acid when analyzed in terms of absolute value of $\mathrm{p} K_{\mathrm{a}}$, both in the free and in its corresponding complexes.
The variation of $\Delta E_{1 / 2}\left(E_{1 / 2}^{\mathrm{P}}-E_{1 / 2} \mathrm{D}\right)$ follows the same trend of $\Delta \mathrm{p} K_{\mathrm{a}}$, meaning that the acidity of the coordinated ligand increases with increasing polarizability and electronegativity of the metal, both factors leading to an increase in the covalency of the $\mathrm{M}-\mathrm{L}$ bond. In order to understand the importance of the factors involving the $\mathrm{MX}_{5}$ units in this comparison, one must point out the nature of their coligands. In this way, one can correlate the greater $\Delta \mathrm{p} K_{\mathrm{a}}$ and $\Delta E_{1 / 2}$ in the pentaammineruthenium derivatives with the less $\sigma$-donor capability of $\mathrm{NH}_{3}$ than the others (edta or $\mathrm{CN}^{-}$).

Table 1 also shows that there is a greater stabilization of the oxidized metal ion when it is coordinated to the deprotonated ligand, which is more basic (donor). In fact, in all the cases, $E_{1 / 2} \mathrm{D}$ is around $200 \mathrm{mV}$ shifted to lower potentials than $E_{1 / 2}$ P. Besides, the reduced species, $\mathrm{M}^{\mathrm{II}}$ $\mathrm{LH}$, have $\mathrm{p} K_{\mathrm{a}}$ values about a $3.5 \mathrm{pH}$ unit higher than the oxidized ones, $\mathrm{M}^{\mathrm{III}}-\mathrm{LH}^{+}$. This could be expected due to the $\mathrm{M}^{\mathrm{II}}-d \pi^{6}$ ion being able to promote a greater stabilization of the whole complex by means of $\pi$-backbonding in direction to the (more $\pi$-acceptor/acid) protonated ligand. On the other hand, the oxidized ion, $\mathrm{M}^{\mathrm{III}}-d \pi^{5}$ (Lewis acid), is better stabilized through the $\sigma, \pi$-donor interactions from the anionic deprotonated ligand. These correlations are also reflected on the LMCT and MLCT spectral data comparison in Table 2. 


\section{Conclusions}

The transition metal complexes outlined in this article constitute simple examples of efficient models for the study and exploitation of PCET reactions. That is because, although in principle any redox reaction with rapid change in proton content gives rise to $\mathrm{pH}$-dependent redox couple, the systems reported here satisfy a number of additional factors and criteria related to such phenomena. Their most important characteristics are listed as follows: (i) oneelectron/one-proton couples in the solvent window; while many examples in the literature 5 involve many coupled proton or electron processes in successive steps; (ii) wide $\mathrm{pH}$ and potential range where the PCET takes place; in the studied examples $\Delta \mathrm{p} K_{\mathrm{a}}\left(\mathrm{p} K_{\mathrm{a}}{ }_{\mathrm{II}}-\mathrm{p} K_{\mathrm{a}}{ }_{\mathrm{a}}{ }^{\mathrm{II}}\right)$ is typically higher than $3 \mathrm{pH}$ units (reaching the value of $4 \mathrm{pH}$ units in some cases), and $\Delta E_{1 / 2}\left(E_{1 / 2}{ }^{\mathrm{P}}-E_{1 / 2} \mathrm{D}\right)$ lies around $200 \mathrm{mV}$ or higher; these parameters define not only the full region of $\mathrm{pH}$-dependent behavior but also describe the related square thermodynamic cycle; (iii) stable and substitutionally inert in both oxidation states, making the couple chemically reversible; besides, the coordination sphere is saturated in all examples, avoiding secondary $\mathrm{pH}$ dependence due to aqua ligands; (iv) rapid heterogeneous electron transfer kinetics between the surface of the electrode and the chemical reactant interface, making the couple electrochemically reversible, as indicated by the small peakto-peak splitting ( $\Delta E_{\mathrm{p}}$ near $60 \mathrm{mV}$ in all examples) and equal peak current ratios in cyclic voltammograms; (v) highly water soluble at all $\mathrm{pH}$ in both oxidation states; while many literature examples comprehend systems poorly or not soluble in water, making necessary the use of mixed solvents, such as acetonitrile/water 5,40 .

In this idea, the best model among the investigated systems in this work would be represented by the $\left[\mathrm{Ru}\left(\mathrm{NH}_{3}\right)_{5}(\mathrm{btaH})\right]^{2+}$ complex, even though all the other benzotriazole ones present an accessible and wide PCET region. The imidazole derivatives have in turn a little disadvantage in relation to the triazole analogues due to the high intrinsic basicity of the ligand, that usually results in high $\mathrm{p} K_{\mathrm{a}}$ values in their transition metal complexes.

As a final remark, the comparison of the PCET properties in complexes of the same family (i.e. the ones containing the same substituted ligand; e.g. M-btaH or M-bimH) can be understood purely in terms of the electronic nature of the starting metallic unit (M) and pi-bonding effects. The consideration of the inductive (through bond) and field (through space) sigma-bonding effects are not relevant, since they are proportional to $\mathrm{Z} / r$ (i.e. the charge of the ion and the ionic radius), which is very similar for all the investigated ruthenium and iron complexes. In addition, the distance from the center ion to the ionizable proton is practically identical for all the series.

\section{Acknowledgements}

The authors thank FAPESP, CNPq and PADCT for their financial support.

\section{References}

1. (a) Marcus, R. A. Annu. Rev. Phys. Chem. 1964, 15, 155. (b) Ulstrup, J. Charge Transfer Processes in Condensed Media; Springer-Verlag; Berlin, 1979.

2. Pourbaix, M. Atlas of Electrochemical Equilibria in Aqueous Solution; 2nd ed.; Permagon Press; Oxford, 1974.

3. (a) Babcock, G. T.; Wikström, M. Nature 1992, 356, 301; (b) Malmström, B. G. Acc. Chem. Res. 1993, 26, 332; (c) Tommos, C.; Babcock, G. T. Acc. Chem. Res. 1998, $31,18$.

4. Cukier, R. I.; Nocera, D. G. Annu. Rev. Phys. Chem. 1998, 49, 337; and references cited therein.

5. Spencer, S. J.; Blaho, J. K.; Lehnes, J.; Goldsby, K. A. Coord. Chem. Rev. 1998, 174, 391; and references cited therein.

6. (a) Birge, R. R. Annu. Rev. Phys. Chem. 1990, 41, 683; (b) Scherl, M.; Haarer, D.; Fisher, J.; DeCian, A.; Lehn, J.-M.; Eichen, Y. J. Phys. Chem. 1996, 100, 16175.

7. (a) Seddon, E. A.; Seddon, K. R. In The Chemistry of Ruthenium; Clark, R. J. H., Ed. Elsevier Science Pub.; Amsterdam, 1984; (b) Balzani, V.; Juris, A.; Venturi, M.; Campagna, S.; Serroni, S. Chem. Rev. 1996, 96, 759; and references cited therein.

8. (a) Toma, H. E.; Malin, J. M. Inorg. Chem. 1973, 12, 1039; (b) Haim, A. Adv. Chem. Ser. 1997, 253, 239; and references cited therein; (c) Moreira, I. D.; Franco, D. W. Adv. Chem. Ser. 1997, 253, 255; and references cited therein.

9. Toma, H. E.; Malin, J. M. Inorg. Chem. 1973, 12, 2080.

10. (a) Reedijk, J. In Comprehensive Coordination Chemistry; Wilkinson, G., Gillard, R. D., McCleverty, J. A., Eds. Pergamon Press; Oxford, 1987; Vol. 2; (b) Constable, E. C.; Steel, P. J. Coord. Chem. Rev. 1989, 93, 205; (c) Steel, P. J. Coord. Chem. Rev. 1990, 106, 227.

11. (a) Guss, J. M.; Merritt, E. A.; Phizackerley, R. P.; Hedman, B.; Murata, M.; Hodgson, K. O.; Freeman, H. C. Science 1988, 241, 806; (b) Godden, J. W.; Turley, S.; Teller, D. C.; Adman, E. T.; Liu, M.-Y.; Payne, W. J.; LeGall, J. Science 1993, 253, 3104.

12. Sundberg, R. J.; Martin, R. B. Chem. Rev. 1974, 74, 471. 
13. (a) Haga, M. Inorg. Chim. Acta 1983, 75, 29; (b) Hatzidimitriou, A.; Gourdon, A.; Devillers, J.; Launay, J.-P.; Mena, E.; Amouyal, E. Inorg. Chem. 1996, 35, 2212; (c) Iwamoto, M.; Alessio, E.; Marzilli, L. G. Inorg. Chem. 1996, 35, 2384; (d) Reddy, K. B.; Cho, M. O. P.; Wishart, J. F.; Emge, T. J.; Isied, S. S. Inorg. Chem. 1996, 35, 7241; (e) Clarke, M. J.; Stubbs, M. Met. Ions Biol. Syst. 1996, 32, 727.

14. (a) Long, C.; Vos, J. G. Inorg. Chim. Acta 1984, 89, 125; (b) Hage, R.; Dijkhuis, A. H. J.; Haasnoot, J. G.; Prins, R.; Reedijk, J.; Buchanan, B. E.; Vos, J. G. Inorg. Chem. 1988, 27, 2185; (c) Hage, R.; Haasnoot, J. G.; Nieuwenhuis, H. A.; Reedijk, J.; Deridder, D. J. A.; Vos, J. G. J. Am. Chem. Soc. 1990, 112, 9245; (d) Serroni, S.; Campagna, S.; Denti, G.; Keyes, T. E.; Vos, J. G. Inorg. Chem. 1996, 35, 4513; (e) Muller, E.; Nazeeruddin, M. K.; Gratzel, M.; Kalyanasundaram, K.; Prome, J. C. New J. Chem. 1996, 20, 759; (f) Lees, A. C.; Evrard, B.; Keyes, T. E.; Vos, J. G.; Kleverlaan, C. J.; Alebbi, M.; Bignozzi, C. A. Eur. J. Inorg. Chem. 1999, 2309.

15. (a) Mansfeld, F.; Smith, T.; Parry, E. P. Corrosion 1971, 27, 289; (b) Walker, R. Corrosion 1973, 29, 290; (c) Walker, R. J. Chem. Educ. 1980, 57, 789.

16. (a) Wilson, R. F.; Joe, F. L. J. Inorg. Nucl. Chem. 1960 , 15, 255; (b) Wilson, R. F. Z. Anorg. Allg. Chem. 1962, 318, 233; (c) Olby, B. G.; Robinson, S. D.; Hursthouse, M. B.; Short, R. L. Polyhedron 1988, 7, 1781; (d) Henn, M.; Alessio, E.; Mestroni, G.; Calligaris, M.; Attia, W. M. Inorg. Chim. Acta 1991, 187, 39; (e) Fukumoto, T.; Kikuchi, A.; Umakoshi, K.; Sasaki, Y. Inorg. Chim. Acta 1998, 283, 151; (f) Pifferi, C.; Cini, R. J. Chem. Soc., Dalton Trans. 1998, 2679.

17. Toma, H. E.; Giesbrecht, E.; Rojas, R. L. E. Can. J. Chem. 1983, 61, 2520.

18. Toma, H. E.; Giesbrecht, E.; Rojas, R. L. E. J. Chem. Soc., Dalton Trans. 1985, 2469.

19. Rocha, R. C.; Araki, K.; Toma, H. E. Transition Met. Chem. 1998, 23, 13.

20. Rocha, R. C.; Araki, K.; Toma, H. E. Inorg. Chim. Acta 1999, 285, 197.

21. Rocha, R. C.; Toma, H. E. Can. J. Chem. 2001, 79, 145.
22. Rocha, R. C.; Toma, H. E. Inorg. Chim. Acta 2000 , $310,65$.

23. Brauer, G. Handbook of Preparative Inorganic Chemistry; 2nd ed.; Academic Press; New York, 1965; Vol. 2; p 1511.

24. Vogt, L. H.; Katz, J. L.; Wiberly, S. E. Inorg. Chem. 1965, 4, 1157.

25. (a) Mukaida, M.; Okuno, H.; Ishimori, T. Nippon Kagaku Zasshi 1965, 86, 589; (b) Yoshino, Y.; Uehiro, T.; Saito, M. Bull. Chem. Soc. Jpn. 1979, 52, 1060.

26. (a) Taqui-Khan, M. M.; Ramachandraiah, G. Inorg. Chem. 1982, 21, 2109; (b) Baar, R. B.; Anson, F. C. J. Electroanal. Chem. 1985, 187, 265.

27. Britton, H. T. S.; Robinson, R. A. J. Chem. Soc. 1931, 458, 1456.

28. Ford, P.; Rudd, D. F. P.; Gaunder, R.; Taube, H. J. Am. Chem. Soc. 1968, 90, 1187.

29. Matsubara, T.; Creutz, C. Inorg. Chem. 1979, 18, 1956.

30. In the specific example involving the benzimidazole complex, the $\mathrm{pH}$-independent region related to the $\mathrm{M}^{\mathrm{III}} \mathrm{L}+\mathrm{e}^{-} \rightarrow \mathrm{M}^{\mathrm{II}} \mathrm{L}^{-}$reaction could not be reached, due to the high value for $\mathrm{p} K_{\mathrm{a}}$ of the reduced species, $\mathrm{p} K_{\mathrm{a}}^{\mathrm{II}}$ (see Discussion section).

31. Toma, H. E.; Malin, J. M. Inorg. Chem. 1974, 13, 1772.

32. (a) Moyer, B. A.; Meyer, T. J. Inorg. Chem. 1981, 20, 436; (b) Johnson, C.; Henderson, W.; Shepherd, R. E. Inorg. Chem. 1984, 23, 2754.

33. (a) Rein, F. N.; Rocha, R. C.; Toma, H. E. J. Electroanal. Chem. 2000, 494, 21; (b) Rein, F. N.; Rocha, R. C.; Toma, H. E. J. Coord. Chem. 2001, 53, 99.

34. Bard, A. L.; Faulkner, L. R. Electrochemical Methods: Fundamentals and Applications; Wiley; New York, 1980.

35. Evans, D. H.; O’Connell, K. M.; Petersen, R. A.; Kelly, M. J. J. Chem. Educ. 1983, 60, 290.

36. Osteryoung, J. J. Chem. Educ. 1983, 60, 296.

37. (a) Campbell, J. A.; Whitaker, R. A. J. Chem. Educ. 1969, 46, 90; (b) Barnum, D. W. J. Chem. Educ. 1982, $59,809$.

38. Waiba, H.; Isensee, R. W. J. Org. Chem. 1961, 26, 2789.

39. Hansen, L. D.; West, B. D.; Baca, E. J.; Blank, C. L. J. Am. Chem. Soc. 1968, 90, 6588.

40. Bond, A.; Haga, M. Inorg. Chem. 1986, 25, 4507.

Received: September 14, 2000

Published on the web: April 4, 2001

FAPESP helped in meeting the publication costs of this article. 